\title{
PROBLEMATIKA PEMBATALAN PUTUSAN ARBITRASE OLEH PENGADILAN (Studi Kasus : PT Geo Dipa Energi (Persero) dengan PT Bumigas Energi)
}

\author{
Siti Chadijah \\ Fakultas Hukum, Universitas Pamulang \\ Email :Schadijaho8@gmail.com
}

Received: Feb 2019 / Revised: Mar 2019 / Accepted: Ags 2019

\begin{abstract}
Dalam UU No.30 Th 1999 tentang Arbitrase dan Alternatif Penyelesaian Sengketa, cara penyelesaian sengketa pada lembaga arbitrase didasarkan atas perjanjian tertulis dari pihak yang bersengketa. Dengan adanya klausula arbitrase dalam perjanjian membawa konsekuensi hukum terkait kompetensi absolut arbitrase terhadap penyelesaian sengketa. Putusan Arbitrase dinyatakan bersifat final dan mengikat, namun demikian terdapat upaya hukum terhadap pembatalan Putusan Arbitrase dengan alasan-alasan yang dapat digunakan untuk membatalkan putusan arbitrase secara limitatif yang termuat dalam Pasal 70 UU No 30 Th 1999, diantaranya : ada dokumen palsu, dokumen yang disembunyikan, dan tipu muslihat. Melihat Putusan PN JAKARTA SELATAN Nomor 529/Pdt.G.ARB/2018/PN JKT.SEL Tahun 2018 (PT Geo Dipa Energi Vs PT Bumigas Energi) yang membatalkan Putusan BANI Nomor 922/II/ARB-BANI/2017 tertanggal 30 Mei 2018 karena ne bis in idem menjadikan suatu problematika terkait alasan-alasan yang dapat digunakan untuk membatalkan putusan di luar yang diatur secara limitatif dalam Pasal 7o UU No. 30 Th 1999.
\end{abstract}

\section{Kata kunci : Putusan Arbitrase, Pembatalan Putusan BANI, Geo Dipa Energi, Bumigas Energi}

\begin{abstract}
Law No. 30 of 1999 on Arbitration and Alternative Dispute Resolution, the method of resolving disputes with arbitration institutions is based on written agreements from the parties to the dispute. With the arbitration clause in the agreement brings legal consequences related to the absolute competence of arbitration against dispute resolution. Arbitration decisions are declared final and binding, however there are legal remedies against the cancellation of the Arbitration Decision for reasons that can be used to cancel the arbitral decision limitatively contained in Article 70 Act No. 30 of 1999. See Decision at South Jakarta District Court Number 529 / Pdt .G.ARB / 2018 / PN JKT.SEL of 2018 (PT Geo Dipa Energy Vs PT Bumigas
\end{abstract}


Energi) which canceled the BANI Decision Number 922 / II / ARB-BANI / 2017 dated 30 May 2018 because ne bis in idem made a related problem reasons that can be used to cancel a ruling outside which is set limitedly in Article 70 of Act No. 30 th 1999 .

\section{Keywords: Arbitral Decision, Annulment of BANI, Geo Dipa Energy, Bumigas Energy}

\section{PENDAHULUAN}

Pada hubungan hukum yang menimbulkan hak dan kewajiban para pihak, misalnya di bidang perdata, tidak dapat dihindari potensi terjadinya sengketa keperdataan. Pengertian sengketa menurut Komar Kantaatmadja ${ }^{\mathrm{I}}$ adalah "keadaan dimana pihak-pihak yang melakukan upaya-upaya perniagaan mempunyai masalah yaitu menghendaki pihak lain untuk berbuat atau tidak berbuat sesuatu tetapi pihak lainnya menolak atau tidak berlaku demikian". Pada suatu hubungan bisnis atau perdagangan di masyarakat timbulnya sengketa tidak dapat dihindarkan karena sengketa dagang merupakan risiko dari hubungan dagang itu sendiri.

Penyelesaian sengketa dengan non litigasi (di luar jalur pengadilan) membutuhkan waktu singkat, cepat, akurat dan final. Selain itu, pihak yang bersengketa tetap terjaga kerahasiaannya meskipun sedang berperkara dengan pihak lain atau mitra dagangnya. Salah satu penyelesaian sengketa dengan non litigasi yakni arbitrase. Ketentuan arbitrase diatur dalam UU No.30 Th 1999 tentang Arbitrase dan Alternatif Penyelesaian Sengketa (selanjutnya disingkat UU. No 30 Th 1999) yang didasarkan atas perjanjian tertulis dari pihak yang bersengketa. Kendati demikian pada dasarnya tidak semua sengketa dapat diselesaikan dengan lembaga arbitrase, melainkan hanya sengketa terkait bidang perdagangan (termasuk industri dan keuangan) dan hak yang menurut hukum dikuasai sepenuhnya oleh para pihak yang bersengketa atas dasar kata sepakat mereka. Berdasarkan kesepakatan para pihak dalam membuat perjanjian yang memuat klausula arbitrase, membawa akibat hukum bahwa kompetensi absolut penyelesaian sengketa adalah lembaga arbitrase bukan pada lembaga pengadilan. Putusan arbitrase bersifat final dan mempunyai kekuatan hukum tetap dan mengikat para pihak (final and binding). Artinya, putusan arbitrase merupakan putusan final dan dengan demikian tidak dapat diajukan banding, kasasi atau peninjauan kembali. ${ }^{2}$

${ }^{1}$ Komar Kantaatmadja, Prospek dan Pelaksanaan Arbitrase di Indonesia, Citra Aditya Bakti, Bandung, 2001, h.37. 
Tujuan dari tidak adanya upaya hukum tersebut di atas untuk menjaga agar jangan sampai penyelesaian sengketa melalui arbitrase menjadi lama atau berlarut-larut. Hal itu membedakan dengan proses pengadilan negeri dimana terhadap putusannya para pihak masih dapat mengajukan banding dan kasasi, sehingga dalam proses penyelesaian sengketa melalui arbitrase tidak terbuka upaya hukum banding, kasasi maupun peninjauan kembali. Namun demikian masih terbuka upaya pembatalan putusan arbitrase di pengadilan negeri atau bahkan upaya penundaan pelaksanaan terhadap putusan arbitrase.

Permasalahan yang terjadi dalam praktiknya, Pengadilan Negeri masih ada yang menerima permohonan pembatalan putusan arbitrase di luar konteks Pasal 70 UU No. 30 Th 1999. Ketentuan Pasal 70 tersebut menyatakan bahwa putusan arbitrase hanya dapat dibatalkan jika diduga mengandung unsur-unsur antara lain, surat/dokumen palsu, atau ditemukan dokumen yang disembunyikan oleh pihak lawan, atau putusan yang diambil dari hasil tipu muslihat yang dilakukan oleh salah satu pihak dalam pmeriksaan sengketa. Salah satu contoh putusan Pengadilan Negeri yaitu pada PN Jakarta Selatan Nomor 529/Pdt.G.ARB/2018/PN JKT.SEL Tahun 2018 (PT Geo Dipa Energi Vs PT Bumigas Energi) yang membatalkan Putusan BANI Nomor 922/II/ARB-BANI/2017 tertanggal 30 Mei 2018 karena ne bis in idem menjadikan suatu problematika terkait alasan-alasan yang dapat digunakan untuk membatalkan putusan arbitrase sebagaimana yang diatur dalam Pasal 7o UU No. 30 Th 1999 seperti diantaranya : ada dokumen palsu, dokumen yang disembunyikan, dan tipu muslihat.

\section{PERMASALAHAN}

Dari pendahuluan yang telah dijelakan di atas, timbul permasalahan sebagai berikut : Apakah Pembatalan Putusan Pengadilan Negeri yaitu pada PN Jakarta Selatan Nomor 529/Pdt.G.ARB/2018/PN JKT.SEL Tahun 2018 (PT Geo Dipa Energi Vs PT Bumigas Energi) yang membatalkan Putusan BANI Nomor 922/II/ARB-BANI/2017 sah secara hukum menurut UU No 30 Th 1999 tentang Arbitrase dan Alternatif Penyelesaian Sengketa?

\footnotetext{
${ }^{2}$ Pasal 60 UU No. 30 Th 1999 dan penjelasannya
} 


\section{METODOLOGI PENELITIAN}

Penulis akan menjawab permasalahan yang timbul mengenai pembatalan putusan arbitrase oleh pengadilan melalui pendekatan undangundang (statute approach), pendekatan konseptual (conseptual approach) dan pendekatan kasus (case approach).

Pendekatan undang-undang (statute approach) dilakukan dengan menelaah semua undang-undang, teori, serta doktrin yang berkaitan dengan arbitrase sebagai salah satu penyelesaian sengketa alternatif. Diawali dengan inventarisasi terhadap berbagai undang-undang, kemudian dilanjutkan dengan kategorisasi serta analisa rasio legis tujuan dibentuknya UU No.30 Th 1999. Masalah pendekatan ini dapat diketahui konsistensi dan kesesuaian antara satu undang-undang dengan undang-undang lainnya, atau antar undang-undang dangan regulasi yang lainnya. Hasil telaah tersebut merupakan salah satu argumen untuk memecahkan kasus hukum yang dihadapi.

Pendekatan konsep (conseptual approach) digunakan untuk memberikan jawaban bagaimana sesungguhnya prinsip final and binding putusan arbitrase serta prinsip pembatalan putusan arbitrase yang terdapat dalam UU No 30 Th 1999 dan peraturan perundang-undangan lain yang berkaitan. Pendekatan kasus (case approach) adalah dengan melakukan analisa terhadap putusan pengadilan dalam salah satu kasus yang dijadikan acuan pada penulisan yaitu putusan pada PN Jakarta Selatan Nomor 529/Pdt.G.ARB/2018/PN JKT.SEL Tahun 2018 (PT Geo Dipa Energi Vs PT Bumigas Energi) yang membatalkan Putusan BANI Nomor 922/II/ARB-BANI/2017 ini dimana pengadilan membatalkan putusan karena ne bis in idem. Putusan pengadilan tersebut dianalisa guna mengetahui bagaimana substansi maupun pertimbangan (ratio decidendi) yang digunakan sebagai dasar putusan, dikaitkan dengan aturan hukum, prinsip-prinsip dan doktrin yang berkaitan dengan arbitrase sebagai salah satu alternatif penyelesaian sengketa.

\section{PEMBAHASAN}

\section{Kompetensi Absolut Penyelesaian Sengketa melalui Arbitrase}

Yurisdiksi arbitrase muncul ketika ada klausul mengenai pilihan yurisdiksi atau pilihan forum di dalam perjanjian, yang menyebutkan bahwa arbitrase merupakan badan penyelesaian sengketa yang dipilih oleh para pihak untuk menyelesaiakan sengketa yang timbul di antara mereka, klausul tersebut disebut sebagai klausul arbitrase. Pada prinsipnya pihakpihak yang terlibat dalam suatu kontrak diberikan kebebasan untuk 
menentukan hukum mana yang berlaku dan forum penyelesaian sengketa mana yang diberlakukan ketika di kemudian hari terjadi suatu sengketa. Hal inilah yang dikenal dengan prinsip party autonomy.

Van Den Berg menjelaskan tentang prinsip party autonomy sebagai berikut : "the principle of party autonomy as a principle of good behavior: courts and arbitrators must accept the autonomy of the parties. It is for a party to decide if and against whom and about what it proceeds. The party also has the initiative to start and to finish a procedure if necessary in consultation with the other party". 3 Dengan prinsip otonomi ini para pihak dapat mengembangkan, menginovasi atau menciptakan bentuk-bentuk kontrak yang mereka inginkan dan sepakati.

Prinsip penting arbitrase lainnya mengenai yurisdiksi arbitrase adalah prinsip competence-competence. Berdasarkan prinsip ini, lembaga arbitrase memiliki kewenangan untuk menentukan sendiri apakah dirinya memiliki yurisdiksi untuk mendengar dan memutus sengketa terkait dengan keabsahan suatu perjanjian atau klausul arbitrase. ${ }^{4}$ Bertolak dari uraian di atas, apabila ada para pihak yang mempersoalkan keabsahan suatu klausul arbitrase maka untuk menentukan pihak yang berhak memutus kewenangan tersebut adalah bukan Pengadilan Negeri atau badan peradilan lainnya melainkan badan arbitrase yang paling berhak. ${ }^{5}$ Menurut Huala Adolf, UU No.30 Th 1999 tidak secara eksplisit mengatur atau memuat prinsip competence-competence disebabkan ketentuan yang terkait dengan kewenangan arbitrase atau majelis arbitrase di dalam menentukan kewenangannya, tidak secara langsung menyangkut kewenangan arbitrase dengan jurisdiksi. ${ }^{6}$ Namun kekosongan mengenai prinsip competencecompetence dalan UU No. 30 Th 1999 tidak berlaku bagi Peraturan Prosedur BANI, terlihat di dalam Pasal I8 ayat (I) Peraturan Prosedur BANI menyatakan: "Majelis berhak menyatakan keberatan atas pernyataan bahwa ia tidak berwenang, termasuk keberatan yang berhubungan dengan adanya atau keabsahan perjanjian arbitrase jika terdapat alasan untuk itu."7

Kewenangan absolut arbitrase yang timbul dari adanya suatu klausul atau perjanjian arbitrase dipertegas dengan yang dinyatakan dalam Pasal 3

${ }^{3}$ Van Den Berg, R. Van Delden, H.J.Sniders, Netherlands Arbitration Law, Kluwer Law and Taxation Publishers, Boston, 1993, p.19.

${ }^{4}$ Margaret L. Moses, Op.CIt, p. 87.

${ }^{5}$ Iqbal, Muhamad. "IMPLEMENTASI EFEKTIFITAS ASAS OPORTUNITAS DI INDONESIA DENGAN LANDASAN KEPENTINGAN UMUM." Jurnal Surya Kencana Satu: Dinamika Masalah Hukum dan Keadilan 9.1 (2018).

${ }^{6}$ Huala Adolf, Dasar-Dasar, Prinsip, dan Filosofi Arbitrase, Keni Media, Bandung, 2014, h. 131.

${ }^{7}$ Ibid.,h.133. 
UU No. 30 Th 1999, yaitu bahwa Pengadilan Negeri tidak berwenang untuk mengadili sengketa para pihak yang telah terikat dalam perjanjian arbirase. Selanjutnya yurisdiksi tersebut dikuatkan dalam Pasal in ayat (I) UU No. 30 Th 1999 yang menentukan bahwa adanya suatu perjanjian arbitrase tertulis meniadakan hak para pihak untuk mengajukan penyelesaian sengketa atau beda pendapat yang termuat dalam perjanjiannya ke Pengadilan Negeri. Pada ayat (2) nya disebutkan bahwa Pengadilan Negeri wajib menolak dantidak akan campur tangan di dalam suatu penyelesaian sengketa yang telah ditetapkan melalui arbitrase, kecuali dalam hal tertentu yang ditetapkan dalam UU No. $30 \mathrm{Th}$ I999. Dalam pengaturan pasal-pasal tersebut termuat prinsip pembatasan intervensi pengadilan (limited court involvement).

\section{Prinsip Final and Binding Putusan Arbitrase}

Pada dasarnya putusan arbitrase bersifat final and binding yang diatur dalam UU No. 30 Th 1999 yaitu tercantum pada Pasal 6o: "Putusan arbitrase bersifat final dan mempunyai kekuatan hukum tetap dan mengikat para pihak". Putusan bersifat final merupakan keputusan tingkat akhir yang artinya tidak terdapat upaya hukum apapun yang dapat dilakukan oleh para pihak apabila putusan dijatuhkan oleh arbiter atau majelis arbitrase sehingga lebih menghemat waktu. Binding diartikan bahwa putusan arbitrase tersebut mengikat kedua belah pihak yang bersengketa, oleh karena itu para pihak seharusnya menerima konsekuensi yuridis terhadap putusan yang dijatuhkan.

Peraturan Prosedur BANI, Pasal 32 secara tegas menyatakan bahwa putusan arbitrase bersifat final dan mengikat para pihak. Dalam putusan tersebut, Majelis menetapkan suatu batas waktu bagi pihak yang kalah untuk melaksanakan putusan dimana dalam putusan Majelis dapat menetapkan sanksi dan/atau denda dan/atau tingkat bunga dalam jumlah yang wajar apabila pihak yang kalah lalai dalam melaksanakan putusan itu. Dari ketentuan tersebut, BANI telah mengatur secar tegas kekuatan mengikat putusan arbitrase serta konsekuensinya bagi para pihak. Sifat seperti ini merupakan salah satu tuntutan pokok putusan arbitrase yang menghendaki proses yang sederhana dan cepat. Putusan dapat langsung dieksekusi dengan cara menutup upaya banding dan atau kasasi.

Selanjutnya, penegasan sifat final and binding putusan arbitrase juga tercantum dalam Article 53 (I) International Center for the Settlement of Investment Disputes (ICSID) yang berbunyi: 
"The award shall be binding on the parties and shall not be subject to any appeal or to any other remedy except those provided for in this Convention. Each party shall abide by and comply with the terms of the award except to the extent that enforcement shall have been stayed pursuant to the relevant provision of this Convention".

Berdasarkan ketentuan ini, putusan arbitrase ICSID langsung mengikat para pihak dan tidak ada upaya banding maupun upaya lain kecuali yang ditentukan dalam konvensi. Upaya yang dibenarkan menurut konvensi ini misalnya permintaan interpretasi atau revisi atau pembatalan putusan arbitrase. Oleh karena itu, pada dasarnya setiap pihak terikat sepenuhnya kepada putusan dan harus menaati serta memenuhi syaratsyarat yang ditentukan dalam putusan.

Sejalan dengan peraturan tersebut di atas, penegasan sifat final and binding putusan arbitrase juga terdapat dalam Pasal 32 ayat (2) UNCITRAL, yang berbunyi: "The award shall be made in writing and shall be final and binding on the parties. The parties under take to carry out the award without delay". Ketentuan ini menegaskan bahwa putusan langsung bersifat final and binding terhadap para pihak. Para pihak wajib langsung melaksanakan putusan tanpa ditunda-tunda dan tidak ada alasan yang dapat dipergunakan untuk menunda-nunda pemenuhan putusan. Melekatnya sifat final and binding dalam putusan arbitrase terhitung sejak salinan putusan (copy of the award) disampaikan oleh Mahkamah Arbitrase kepada para pihak.

Berdasarkan hal-hal tersebut di atas, maka putusan arbitrase memiliki kekuatan mengikat terhadap para pihak yang bersengketa pada tingkat akhir dan merupakan putusan yang berkekuatan hukum tetap (inkracht van gewisjde). Sebagai konsekuensi dari sifat putusan arbitrase yang final and binding, maka para pihak wajib langsung melaksanakan putusan tersebut. Namum pelaksanaan putusan arbitrase secara sukarela ini sangat bergantung pada itikad baik para pihak yang bersengketa.

\section{Pembatalan Putusan Arbitrase}

Pada prinsipnya putusan arbitrase bersifat final and binding, sehingga merupakan putusan pada tngkat terakhir dan mengikat para pihak. Tidak terbuka upaya hukum banding ataupun kasasi seperti putusan Pengadilan Negeri. Namun demikian karena beberapa hal dimungkinkan untuk melakukan pembatalan putusan arbitrase. Pembatalan putusan arbitrase ini hanya dapat dilakukan jika terdapat "hal-hal yang bersifat luar biasa". Suatu putusan yang telah dibatalkan 
sudah melenyapkan secara keseluruhan wujud fisik maupun nilai yuridisnya. Seolah-olah sengketa itu belum pernah diproses dan diputus. Putusan benar-benar secara mutlak dianggap belum pernah ada. ${ }^{8}$ Akibatnya, secara otomatis proses eksekusi atas putusan arbitrase tersebut tidak akan pernah dilaksanakan.

\section{Alasan-Alasan Pembatalan Putusan Arbitrase}

UU No. 30 th 1999 mengatur tentang pembatalan putusan arbitrase dalam Pasal 70 yang menyatakan bahwa terhadap putusan arbitrase para pihak dapat mengajukan permohonan pembatalan apabila putusan tersebut diduga mengandung unsur-unsur sebagai berikut:

a. surat atau dokumen yang diajukan dalam pemeriksaan, setelah putusan dijatuhkan, diakui palsu atau dinyatakan palsu;

b. setelah putusan diambil ditemukan dokumen yang bersifat menentukan, yang disembunyikan oleh pihak lawan;dan

c. putusan diambil dari hail tipu muslihat yang dilakukan oleh salah satu pihak dalam pemeriksaan sengketa.

Selanjutnya dalam Pasal 58 UU No. 30 Th 1999 menyatakan: "Dalam waktu paling lama I4 (empat belas) hari setelah putusan diterima, para pihak dapat mengajukan permohonan kepada arbiter atau majelis arbitrase untuk melakukan koreksi terhadap kekeliruan administratif dan atau menambah atau mengurangi sesuatu tuntutan putusan. Dari ketentuan pasal tersebut, dapat disimpulkan bahwa UU No. 30 Th 1999 menghendaki agar apabila suatu putusan telah mengabulkan sesuatu yang tidak dituntut, atau tidak memuat satu atau lebih hal yang diminta untuk diputus, maka terhadap putuan tersebut selayaknya hanya dilakukan penambahan atau pengurangan, dan tidak dilakukan pembatalan putusan arbitrase.

Kemudian pada bagian penjelasan Pasal 70 menyebutkan bahwa alasan-alasan permohonan pembatalan yang disebut dalam pasal ini harus dibuktikan dengan putusan pengadilan. Ketentuan ini menimbulkan multitafsir, sebab undang-undang tidak menjelaskan apakah alasan-alasan pembatalan tersebut harus diperiksa dan diputus lebih dahulu oleh majelis hakim yang berbeda dengan majelis hakim yang memeriksa permohonan pembatalan putusan arbitrase, ataukah dapat dilakukan oleh majelis yang h. 141 .

${ }^{8}$ Bambang Sutiyoso, Penyelesaian Sengketa Bisnis, Citra Media, Yogyakarta, 2006, 
sama. Penjelasan Pasal 70 yang menimbulkan kerancuan dan ketidakpastian hukum diajukan uji materi ke Mahkamah Konstitusi. Mahkamah Konstitusi dalam putusannya yang bernomor 15/PUU/XII/2014 mengabulkan uji materi penjelasan Pasal 7o UU No. 30 Th 1999 dan menyatakan bahwa penjelasan Pasal 7o bertentangan dengan Undang-Undang Dasar Negara Republik Indonesia Tahun 1945 (UUD 1945) dan tidak mempunyai kekuatan hukum mengikat.

Hakim Mahkamah Kosntitusi menilai Pasal 7o UU AAPS sudah cukup jelas (expressis verbis), sehingga tidak perlu ditafsirkan lain. Selain itu, Pasal 70 tidak bisa dilepaskan dengan Pasal 7I terkait jangka waktu penyelesaian perkarapembatalan putusanarbitraseyang diajukan hanya selama 30 hari di pengadilan. Sebab, tidak mungkin jangka waktu 30 hari bisa diputuskan, termasuk kalau diajukan keberatan (banding) ke di MA. Artinya, Penjelasan Pasal 70 itu tidak bisa diterapkan apabila alasan permohonan pembatalan harus dengan putusan pengadilan (pidana) terkait pembuktian pemalsuan atau penggelapan dokumen, adanya tipu muslihat. 9 Dengan adanya putusan Mahakamah Kosntitusi tersebut, para pihak akan mudah mengajukan pembatalan atas putusan-putusan arbitrase yang mengandung tiga unsur, yakni unsur tipu muslihat, adanya dugaan pemalsuan, atau dugaan konspirasi ke pengadilan, sehingga tidak ada lagi hambatan bagi pihak-pihak yang merasa dirugikan atas putusan arbritase untuk mengajukan permohonan pembatalan.

\section{Sifat Pasal 70 UU No. 30 Th 1999 sebagai dasar pembatalan putusan arbitrase}

Alasan pembatalan putusan arbitrase yang dimuat dalam Pasal 70 UU No. 30 Th 1999 adalah sebagai berikut: "Terhadap putusan arbitrase para pihak dapat mengajukan permohonan pembatalan apabila putusan tersebut diduga mengandung unsur-unsur sebagai berikut:

a. surat atau dokumen yang diajukan dalam pemeriksaan, setelah putusan dijatuhkan, diakui palsu atau dinyatakan palsu;

b. setelah putusan diambil ditemukan dokumen yang bersifat menentukan, yang disembunyikan oleh pihak lawan;dan

c. putusan diambil dari hail tipu muslihat yang dilakukan oleh salah satu pihak dalam pemeriksaan sengketa.

Berdasarkan ketentuan Pasal 70 tersebut, kata "sebagai berikut" memiliki makna alasan-alasan pembatalan putusan arbitrase hanya terbatas

9 http://www.hukumonline.com/mk-perjelas-alasan-pembatalan-putusan-arbitrase, diakses pada tanggal 27 Juni 2019 
pada 3 (tiga) alasan yang di atur dalam undang-undang. Permohonan pembatalan harus didasarkan alasan-alasan bahwa putusan arbitrase mengandung unsur-unsur tertentu sebagaimana telah ditentukan secara limitatif oleh Pasal 7o, sehingga terhadap permohonan pembatalan putusan arbitrase tidak dapat menggunakan unsur-unsur atau alasan-alasan lain di luar apa yang telah ditentukan dalam pasal tersebut. Menurut Basuki Rekso Wibowo, unsur-unsur yang terdapat dalam Pasal 7o tersebut tidak bersifat kumulatif melainkan bersifat alternatif, artinya apabila suatu putusan arbitrase yang diduga mengandung salah satu dari apa yang dimaksud Pasal 70 maka permohonan pembatalan putusan arbitrase telah dapat diajukan. ${ }^{\text {IO }}$

Sementara itu, Penjelasan Pasal 7o UU No. 30 Th 1999 menyatakan: Alasan-alasan permohonan pembatalan yang disebut dalam pasal ini harus dibuktikan dengan putusan pengadilan. Apabila pengadilan menyatakan bahwa alasan-alasan tersebut terbukti atau tidak terbukti, maka putusan pengadilan ini dapat digunakan sebagai dasar pertimbangan bagi hakim untuk mengabulkan atau menolak permohonan. Penjelasan ini di satu sisi menggariskan, Pemohon harus menyertakan bukti putusan pengadilan untuk mendukung alasan Permohonan. Di sisi lain, memperhatikan kata "dapat" dari kalimat putusan pengadilan ini dapat digunakan sebagai dasar pertimbangan seolah-olah hakim diberi keleluasaan untuk menggunakan atau tidak menggunakan putusan pengadilan tersebut sebagai dasar pertimbangannya.

Perlu diketahui bahwa seperti yang dijelaskan sebelumnya, Penjelasan Pasal 70 yang menimbulkan kerancuan dan ketidakpastian hukum diajukan uji materi ke Mahkamah Konstitusi. Mahkamah Konstitusi dalam putusannya yang bernomor 15/PUU/XII/2014 mengabulkan uji materi penjelasan Pasal 7o UU No. 30 Th 1999 dan menyatakan bahwa penjelasan Pasal 70 bertentangan dengan UndangUndang Dasar Negara Republik Indonesia Tahun 1945 (UUD 1945) dan tidak mempunyai kekuatan hukum mengikat. Dengan demikian alasan permohonan pembatalan putusan arbitrase yang akan digunakan sebagai dasar permohonan tidak perlu dibuktikan terlebih dahulu dengan putusan pengadilan.

Berdasarkan ketentuan Pasal 7I UU No. 30 Th 1999, secara prosedural permohonan pembatalan tersebut diajukan secara tertulis paling lambat 30 hari terhitung sejak penyerahan dan pendaftaran putusan

10 Basuki Rekso Wibowo, Arbitrase Sebagai Alternatif Penyelesaian Sengketa Perdagangan Di Indonesia, Disertasi, Universitas Airlangga, Surabaya, 2004, h. 477. 
abitrase ke Pengadilan Negeri. Tenggang waktu upaya hukum permohonan pembatalan telah ditentukan secara limitatif. ${ }^{\text {II }}$ Dalam pengertian, apabila terdapat keberatan dari termohon ekskusi, maka dalam tempo 30 hari setelah putusan arbitrase secara resmi didaftarkan harus sudah diajukan upaya hukum permohonan pembatalan.

Dalam prakteknya pembatalan putusan arbitrase oleh Pengadilan Negeri hingga Mahkamah Agung masih mengalami ketidakseragaman dan inkonsistensi berkaitan dengan penggunaan alasan-alasan pembatalan putusan arbitrase dalam Pasal 70 UU No. 30 Th 1999. Pada satu sisi, Mahkamah Agung menginterpretasikan alasan-alasan dalam ketentuan tersebut sebagai alasan yang bersifat limitatif. ${ }^{12}$ Namun demikian, dalam beberapa putusan yang lain Mahkamah Agung menginterpretasikannya sebagai alasan yang tidak limitatif. ${ }^{13}$

\section{Kasus Posisi PT Geo Dipa Energi Vs PT Bumigas Energi}

Kasus ini bermula dari permohonan yang diajukan PT Geo Dipa Energi (Selanjutnya disingkat GDE) kepada BANI pada Februari 2017 terhadap hasil Putusan MA No.45 PK/ Pdt.Sus-Arbt/2015 tanggal 28 Mei 2015, telah menghasilkan Putusan BANI No.922/II/ARB-B/2017 pada 30 Mei 2018. Putusan tersebut menyatakan PT Bumigas Energi (Selanjutnya disingkat Bumigas) gagal menyediakan dana sesuai ketentuan Pasal 55 Kontrak dan menyatakan Kontrak dinyatakan berakhir terhitung 30 Mei 2018.

Selanjutanya, pada I9 September 2017, Komisi Pemberantasan Korupsi (KPK) cq Deputi Pencegahan melalui surat No.B/oo4/LIT.o4/ro15/09/2017 telah mengeluarkan surat kepada GDE bahwa Bumigas tidak pernah memiliki rekening di HSBC Hongkong baik dalam status aktif

\section{${ }^{11}$ Ibid.,h.481}

12 Sebagai contoh ialah Putusan MA Nomor 320 K/Pdt/2007 antara Perum Peruri melanggar PT. Pura Barutama. PN Kudus dalam putusannya membatalkan putusan BANI dengan menggunakan alasan di luar dari ketentuan Pasal 70 UU No. 30 Th 1999. Namun demikian, di tingkat banding MA membatalkan putusan PN Kudus tersebut dengan pendapat bahwa alasan permohonan pembatalan putusan arbitrase yang dapat diajukan hanya alasan yang terdapat dalam UU No. 30 Th 1999. Oleh sebab itu dapat dilihat dalam kasus ini bahwa alasan-alasan yang diatur oleh ketentuan Pasal 70 UU No. 30 Th 1999 ialah bersifat limitatif.

13 Sebagai contoh ialah putusan MA No. 126/PK/Pdt.sus/2010 antara PT. Pembangunan Perumahan melanggar PT. Padjajaran Indah Prima. Dalam kasus ini, MA berpendapat bahwa alasan pembatalan putusan arbitrase yang terdapat di dalam ketentuan Pasal 70 UU No. 30 Th 1999 bersifat tidak limitative. Alasan pembatalan putusan arbitrase dalam kasus ini ialah terdapatanya "kesalahan procedural" yang dilakukan BANI dalam memutus perkara antara PT Pembangunan Perumahan melanggar PT Padjajaran Indah Prima dalam putusan BANI No. 03/2007/BANI Bandung tanggal 17 Maret 2008. 
maupun yang telah ditutup. Padahal rekening HSBC Hongkong adalah rekening yang dinyatakan Bumigas sebagai rekening yang menerima prove of fund pada 29 April 2005 untuk memenuhi ketentuan pasal 55 Kontrak. Apabila ketentuan pasal 55 kontrak ini tidak dipenuhi Bumigas, maka dengan sendirinya kontrak berakhir sejak tanggal I Mei 2005. Surat KPK di atas menunjukkan niat buruk Bumigas dengan menggunakan tipu muslihat kepada GDE sedemikian rupa agar Kontrak berlaku efektif. Selain itu, surat KPK tersebut juga menjadi salah satu bukti oleh GDE pada proses pengadilan di BANI yang menguatkan permohonan GDE untuk menjadi pertimbangan BANI atas permohonan GDE untuk mengakhiri Kontrak.

Kemudian Bumigas kembali mengajukan permohonan (ketiga) pembatalan Putusan BANI No.922/2017 (yang telah memenangkan GDE) kepada PN Jakarta Selatan. Pada 4 September 2018, PN Jakarta Selatan melalui Putusan No.529/Pdt.G.ARB/2018 menyatakan Putusan BANI No.922/2017 dibatalkan. Namun dalam putusan ini, PN Jakarta Selatan tidak menyangkal kebenaran dan keberadaan surat KPK tanggal i9 September $2017 \cdot{ }^{14}$

\section{Analisa Putusan PN Jakarta Selatan Nomor 529/Pdt.G.ARB/2018/PN JKT.SEL Tahun 2018 (PT Geo Dipa Energi Vs PT Bumigas Energi)}

Pengadilan Negeri Jakarta Selatan yang mengadili perkara perdata permohonan pembatalan Putusan Badan Arbitrase Nasional Indonesia (BANI) dalam perkara antara : a) PT Bumigas Energi, selaku Pemohon; melawan b) PT Geo Dipa Energi Persero selaku Termohon, c) Badan Arbitrase Nasional Indonesia cq Majelis Arbitrase Pemeriksa Perkara selaka Turut Termohon. PN Jakarta Selatan membatalkan Putusan BANI Nomor 922/II/ARB-BANI/2017 tertanggal 30 Mei 2018 karena ne bis in idem. Dalam salah satu pertimbangan hukumnya menyatakan bahwa, "dengan telah dinyatakannya Putusan BANI Nomor 922/II/ARB$\mathrm{BANI} / 2017$ tertanggal 30 Mei 2018 telah melanggar asas ne bis in idem, maka dengan sendirinya Putusan BANI Nomor 922/II/ARB-BANI/2017 tertanggal 30 Mei 2018 tersebut harus dinyatakan batal demi hukum" s5.

Melihat pertimbangan hukum putusan tersebut dan dikaitkan dengan ketentuan-ketentuan pada UU No 30 Th 1999 antara lain

14 https://reportaserakyat.com/opini/merugikan-rakyat-iress-batalkan-putusan-ma-kasusbumn-geo-dipa-energi/, diakses pada tanggal 27 Juni 2019

${ }^{15}$ Hlm 174 Putusan No 529/Pdt.G.Arb/2018/PN JKT SEL 
pengaturan terkait pembatalan putusan arbitrase telah diatur dalam Pasal 7o UU No 30 Th 1999 yaitu dengan alasan sebagai berikut; jika surat atau dokumen diakui atau dinyatakan palsu, ditemukan dokumen yang bersifat menentukan yang disembunyikan oleh pihak lawan atau putusan diambil dari tipu muslihat yang dilakukan oleh salah satu pihak dalam pemeriksaan sengketa, sehingga dengan adanya ketentuan pasal tersebut tidak ada alasan pembatalan putusan arbitrase diluar selain yang diatur mengingat frase "sebagai berikut" dalam Pasal 7o UU No. 30 Th 1999 menunjukkan sifat limitative (terbatas) dari alasan-alasan pembatalan putusan arbitrase. Akibat putusan yang menyatakan ne bis in idem yaitu tidak boleh lagi mengajukan permohonan dengan substansi yang sama seperti sebelumnya karena putusan yang terdahulu telah berkekuatan hukum tetap sehingga putusan dinyatakan tidak dapat diterima (niet ontvankelijke verklaard) atau yang biasa disebut sebagai putusan NO.

Menurut penulis, seharusnya asas ne bis in idem tidak dapat diterapkan dalam perkara pembatalan putusan arbitrase karena jika suatu putusan arbitrase dibatalkan, maka demi hukum putusan tersebut dianggap tidak pernah ada dan membawa konsekuensi hukumnya yaitu terhadap sengketa tersebut dapat dilakukan penyelesaian sengketa kembali melalui lembaga arbitrase. Selanjutnya, meneliti kembali dalam UU No 30 Th 1999 khususnya dalam Pasal 72 ayat (2), kiranya dapat diketahui bahwa telah diatur mengenai akibat hukum pasca dibatalkannya putusan arbitrase yaitu : Apabila permohonan sebagaimana dimaksud dalam ayat (I) dikabulkan, Ketua Pengadilan Negeri menentukan lebih lanjut akibat pembatalan seluruhnya atau sebagian putusan arbitrase. Lebih lanjut penjelasan pasal tersebut menentukan bahwa: Ketua Pengadilan Negeri diberi wewenang untuk memeriksa tuntutan pembatalan jika diminta oleh para pihak, dan mengatur akibat dari pembatalan seluruhnya atau sebagian dari putusan arbitrase bersangkutan, Ketua Pengadilan Negeri dapat memutuskan bahwa setelah diucapkan pembatalan, arbiter yang sama atau arbiter lain akan memeriksa kembali sengketa bersangkutan atau menentukan bahwa suatu sengketa tidak mungkin diselesaikan lagi melalui arbitrase.

Berdasarkan penjelasan di atas, dapat ditafsirkan bahwa apabila suatu putusan arbitrase dibatalkan di Pengadilan Negeri karena terbukti mengandung unsur-unsur sebagaimana diatur dalam Pasal 70 UU No 30 Th 1999, maka Hakim Pengadilan Negeri dapat menentukan akibat-akibat lebih lanjut yang pada intinya perkara tersebut dapat diadili kembali, baik oleh arbiter yang sama, arbiter lain atau diselesaikan melalui cara lain selain arbitrase. Dengan demikian, menjadikan terbukanya kesempatan bagi perkara tersebut untuk diadili kembali, oleh karena itu dapat 
disimpulkan bahwa terhadap perkara yang putusan arbitrasenya telah dibatalkan oleh Pengadilan tidak dapat diterapkan asas ne bis in idem.

\section{KESIMPULAN}

Pembatalan putusan arbitrase merupakan perkara perdata yang memiki sifat khusus dan substansinya diatur berdasarkan UU No 30 Th 1999, sehingga dapat dipahami bahwa asas ne bis in idem tidak dapat diterapkan dalam perkara pembatalan putusan arbitrase, hal tersebut merujuk pada Pasal 72 ayat (2) UU No 30 Th 1999. Pasal 7o UU No 30 Th 1999 sudah mengatur cukup jelas (expressis verbis) mengenai pembatalan putusan arbitrase, ditambah lagi dengan adanya Putusan MK Nomor I5/PUU-XII/2014 yang membatalkan penjelasan Pasal 7o dengan implikasi bahwa upaya pembatalan putusan arbitrase dapat diajukan melalui pengadilan dengan catatan terdapat syarat limitative yang harus terpenuhi yaitu adanya unsur dugaan sesuai Pasal 7o tanpa harus dibuktikan terlebih dahulu di pengadilan, sehingga keuntungan proses penyelesaian perkara di lembaga arbitrase lebih cepat serta tidak mudah dibatalkan karena apabila mudah dibatalkan dapat menimbulkan keraguan masyarakat di luar maupun dalam negeri terhadap lembaga arbitrase di Indonesia.

Berdasarkan UU No 30 Th 1999, putusan arbitrase bersifat final and binding, maka dari itu peran dan kewenangan pengadilan dalam proses pemeriksaan pembatalan putusan arbitrase hanya sekedar meneliti fakta tentang benar atau tidak alasan yang disampaikan oleh pemohon, apabila terbukti tidak ada maka permohonan pembatalan putusan arbitrasenya ditolak, sebaliknya apabila memenuhi unsur alasan pembatalan putusan arbitrase, maka Pengadilan Negeri akan menerima permohonan pembatalan putusan arbitrase.

\section{DAFTAR PUSTAKA}

Burgerlijk Wetboek (BW, Stb. Tahun I847, No.23);

Het Herziene Indonesisch Reglement (Reglement Acara untuk Daerah Jawa dan Madura, Stb.194I, No.44);

Rechtsreglement, Stb. 1927, No.227); Buitengewesten (Reglement Acara Untuk Daerah Luar Jawa dan Madura

Reglement op de Burgerlijke Rechtvordering (Reglement Acara untuk Golongan Eropa, Stb. 1847, No. 52 jo. Stb. 1949, No. 6oI);

Undang-Undang Republik Indonesia Nomor 30 Tahun 1999 tentang Arbitrase dan Alternatif Penyelesaian Sengketa (Lembaran Negara Republik Indonesia Tahun 1999 Nomor 138 Tambahan Lembaran Negara Republik Indonesia Nomor 3872); 
Siti Chadijah

Undang-Undang Republik Indonesia Nomor 48 Tahun 2009 tentang Kekuasaan Kehakiman (Lembaran Negara Republik Indonesia Tahun 2009 Nomor 157 Tambahan Lembaran Negara Republik Indonesia Nomor 5076);

Peraturan Prosedur Badan Arbitrase Nasional Indonesia

UNCITRAL Model Law on International Commercial Arbitrationi985 With amendements as adopted in 2006

International Centre for Settlement of Investment Disputes (ICSID) 1966 Putusan Pengadilan Nomor 529/Pdt.G.Arb/2018/PN JKT SEL

Putusan Mahkamah Konstitusi Nomor I5/PUU/XII/20I 
